\title{
Seasonal dynamics of the endosymbiotic, nitrogen-fixing cyanobacterium Richelia intracellularis in the eastern Mediterranean Sea
}

\author{
Edo Bar Zeev ${ }^{1}$, Tali Yogev ${ }^{1}$, Dikla Man-Aharonovich ${ }^{2}$, Nurit Kress ${ }^{3}$, Barak Herut $^{3}$, \\ Oded Béjà ${ }^{2}$ and Ilana Berman-Frank ${ }^{1}$ \\ ${ }^{1}$ Mina and Everard Goodman Faculty of Life Sciences, Bar-Ilan University, Ramat Gan, Israel; ${ }^{2}$ Faculty of \\ Biology, Technion-Israel Institute of Technology, Haifa, Israel and ${ }^{3}$ Israel Oceanographic and Limnological \\ Research, National Institute of Oceanography, Haifa, Israel
}

\begin{abstract}
Biological nitrogen fixation has been suggested as an important source of nitrogen for the ultraoligotrophic waters of the Levantine Basin of the Mediterranean Sea. In this study, we identify and characterize the spatial and temporal distribution of the $\mathrm{N}$-fixing (diazotrophic) cyanobacterium Richelia intracellularis. $R$. intracellularis is usually found as an endosymbiont within diatoms such as Rhizosolenia spp and Hemiaulus spp. and is an important diazotroph in marine tropical oceans. In this study, two stations off the Mediterranean coast of Israel were sampled monthly during 2005-2007. R. intracellularis was identified by microscopy and by reverse transcribed-PCR which confirmed a $\mathbf{9 8 . 8} \%$ identity with known nifH sequences of $\boldsymbol{R}$. intracellularis from around the world. The diatom-diazotroph associations were found throughout the year peaking during autumn (October-November) at both stations. Abundance of $R$. intracellularis ranged from 10 to 55 heterocysts $\mathrm{I}^{-1}$ and correlated positively with the dissolved $\mathrm{Si}(\mathrm{OH})_{4} /\left(\mathrm{NO}_{3}+\mathrm{NO}_{2}\right)$ ratio in surface waters. Although the rates of nitrogen fixation were very low, averaging $\sim 1.1 \mathrm{nmol} \mathrm{N} \mathrm{I}^{-1}$ day $^{-1}$ for the R. intracellularis size fraction $(>10 \mu \mathrm{m})$ from surface waters, they correlated positively with heterocyst counts during thermal stratification. The lack of large-scale diatom-diazotroph blooms and the low rates of nitrogen fixation by these diazotrophs may result from the P-starved conditions affecting the Levantine basin.
\end{abstract}

The ISME Journal (2008) 2, 911-923; doi:10.1038/ismej.2008.56; published online 26 June 2008

Subject Category: microbial population and community ecology

Keywords: Richelia intracellularis; nitrogen-fixation; Mediterranean Sea; cyanobacteria; diatomsdiazotroph symbiosis

\section{Introduction}

Surface oceanic waters around the tropical and subtropical latitudes are commonly oligotrophic. In such nutrient-poor environments, symbiotic relationships are commonly observed and enhance survival via mutual benefits for both partners. Nitrogen is the most abundant substance $(\sim 78 \%)$ in the atmosphere and is essential for creating and sustaining life on earth. Yet, its inert form $\left(\mathrm{N}_{2}\right)$ is metabolically unavailable to most organisms, making the role of nitrogen-fixing organisms (diazotrophs) crucial in N-limited environments.

Correspondence: I Berman-Frank, Faculty of Life Sciences, Bar Ilan University, Building 201, Ramat Gan 52900, Israel.

E-mail: irfrank@mail.biu.ac.il

Received 31 March 2008; revised 29 April 2008; accepted 29 April 2008; published online 26 June 2008
Many symbiotic associations are known between diazotrophs and other organisms from terrestrial symbioses between Rhizobium and legumes to aquatic symbioses between cyanobacterial diazotrophs and phytoplankton such as Richelia intracellularis and diatoms. $R$. intracellularis is a small ( $\sim 10 \mu \mathrm{m}$ in diameter) nitrogen-fixing cyanobacterium spatially segregating nitrogen fixation from photosynthesis and thus fixing atmospheric $\mathrm{N}$ during daytime. It consists of one polar heterocyst (site of nitrogen fixation) and three to 10 vegetative cells (Geitler, 1932). It is usually found as an endosymbiont within diatoms such as Rhizosolenia spp, Hemiaulus spp, or as an episymbiont attached to Chaetoceros spp. (Venrick, 1974; Taylor, 1982; Sundstrom, 1984; Gomez et al., 2005). Diatomdiazotroph associations containing the cyanobiont $R$. intracellularis and the filamentous non-heterocystous Trichodesmium spp., were traditionally 
considered the dominant nitrogen-fixing plankton in marine tropical oceans. The 'New N' supplied by these organisms, and a variety of small unicellular diazotrophs described recently (Zehr et al., 2001; Montoya et al., 2004; Zehr et al., 2007), contribute substantially to these systems (Venrick, 1974; Mague et al., 1977; Carpenter and Romans, 1991; Capone et al., 1997; Carpenter et al., 1999; Arrigo, 2005). In the tropical North Atlantic, extensive $\mathrm{N}_{2}$ fixation by blooms of diatoms and $R$. intracellularis produced nearly $70 \%$ of total $\mathrm{N}$ demand in surface waters (Carpenter et al., 1999; Janson et al., 1999).

The eastern Mediterranean Sea is extremely oligotrophic due to a general west to east antiestuarine circulation, which exports nutrients from the Mediterranean into the North Atlantic (Bethoux et al., 1998). The oligotrophic nature results in a high water clarity, low values of chlorophyll $a(\mathrm{Chl} a$ ), low rates of primary production (Berman et al., 1984; Azov, 1986; Li et al., 1993; Yacobi et al., 1995; Psarra et al., 2000; Tanaka et al., 2007), and dominance by small-sized phytoplankton (Li et al., 1993; Yacobi et al., 1995; Ignatiades et al., 2002). The Levantine basin, located in the easternmost section of the Mediterranean, is the most oligotrophic region within the Mediterranean Sea. Its characteristics are a prominent deep chlorophyll maximum (DCM) at 100-130 $\mathrm{m}$ depth (Li et al., 1993; Yacobi et al., 1995), low phytoplankton biomass ( $\left.<50 \mathrm{ng} \mathrm{Chl} a \mathrm{l}^{-1}\right)$ in the surface layers ( $\mathrm{Li}$ et al., 1993; Vidussi et al., 2001), an average salinity of $\sim 39 \mathrm{psu}$, and sea-surface temperatures between $16-28^{\circ} \mathrm{C}$.

Studies using geochemical and stable isotopic $\left(\delta^{15} \mathrm{~N}\right)$ mass balances have suggested that nitrogen fixation supplies a significant source of new nitrogen to the Mediterranean (Bethoux, 1986; Bonin et al., 1989; Bethoux et al., 1992, 2002; Pantoja et al., 2002). Yet, only recently have actual $\mathrm{N}$ fixation rates been reported from the Mediterranean Sea. One study, from the Western Mediterranean, averaged $\sim 7 \mathrm{nmol} \mathrm{N}^{-1}$ day $^{-1}$ (Garcia et al., 2006) while measurements from a warm-core eddy near Cyprus yielded rates of $\sim 129 \mathrm{nmol} \mathrm{N}^{-1}$ day $^{-1}$ (Rees et al., 2006). However, these studies lack any identification or characterization of the organisms responsible for this fixation.

We recently described a diverse diazotrophic community with differential patterns of nifH expression from an east-west transect off the Israeli coast (Man-Aharonovich et al., 2007). One of the organisms identified was $99 \%$ identical to $R$. intracellularis. Previous observations indicated the presence of the diatoms Rhizosolenia spp. and Hemiaulus hauckii (B Kimor, personal communication), which harbor these cyanobionts although, to date, no published studies exist on their dynamics anywhere within the Mediterranean.

In this study, we focused on the diatom-diazotrophic associations in the eastern Mediterranean and have identified, characterized and followed the seasonal and spatial dynamics of the filamentous nitrogen-fixing cyanobacteria- $R$. intracellularis and its diatom hosts: Rhizosolenia spp. and Hemiaulus spp. at 2 monthly monitored stations off the Mediterranean coast of Israel.

\section{Materials and methods}

Sample collection and processing

Water samples were routinely collected during daytime in monthly cruises (June 2006-May 2007) on board the R/V Mediterranean Explorer. Two stations were sampled: one coastal station TB200 $\left(32^{\circ} 09.982^{\prime} \mathrm{N}\right.$ and $\left.34^{\circ} 34.509^{\prime} \mathrm{E}\right)$ at ca. $200 \mathrm{~m}$ bottom depth and one pelagic station TB1000 (34 $14.909^{\prime} \mathrm{E}$ and $32^{\circ} 10.059^{\prime} \mathrm{N}$ ), at ca. $1000 \mathrm{~m}$ bottom depth. Water samples for molecular distribution, nitrogen fixation and nutrients concentration determination were collected using Niskin bottles (8 l) mounted on a Rosette equipped with a CTD (seabird 19 Plus), insitu fluorometer (Turner designs, Cyclops7) that was calibrated against extracted Chl $a$ in the laboratory.

Samples for cell counts were taken from the surface waters ( $\sim 5 \mathrm{~m}$ depth). A Nytex plankton-net (55-300 $\mu \mathrm{m}$ equipped with a digital flow meter (Hydrobios No 438110) was towed horizontally behind the research vessels and used to compute the total volume of water passing through the net.

Sample collection and processing for cell identification and enumeration

Samples were collected from the net and preserved in $50 \mathrm{ml}$ tubes with $0.5 \%$ gluteraldehyde and stored at $4{ }^{\circ} \mathrm{C}$ in the dark until further examination in the lab. Samples were identified and counted using an epifluorescence microscope (Nikon Eclipse 80i) equipped with three specific filters-chlorophyll fluorescence filter (Ex: $450 \mathrm{~nm}$, Em: $680 \mathrm{~nm}$ ), phycoerythrin fluorescence filter (Ex: $490 \mathrm{~nm}$, Em: $580 \mathrm{~nm}$ ) and phycocyanin fluorescence filter (Ex: 620, Em: $660 \mathrm{~nm}$ ).

Five to 20 replicate samples $(70 \mu \mathrm{l})$ per station/ depth were counted microscopically (with a total of 200 to $>3000$ heterocysts counted depending on abundance). The chloroplasts of the host cell (diatom) were observed using the chlorophyll $a$ filter only while the endosymbiotic cyanobacterium $R$. intracellularis was observed under both phycoerythrin and phycocyanin filter sets. Both the host and the endosymbiont $R$. intracellularis were identified and counted.

\section{Nitrogen fixation rates}

$\mathrm{N}$ fixation was measured on preconcentrated samples using the acetylene reduction technique which measures total nitrogenase activity (Capone, 1993; Montoya et al., 2004) and has also been applied in the field on concentrated samples (Falcon et al., 2002, 2004). Ten to 15 liters were pre-concentrated 
from surface waters $(\sim 5 \mathrm{~m})$ and size fractionated to $1-10 \mu \mathrm{m}, 10-100 \mu \mathrm{m}$ and $>100 \mu \mathrm{m}$ under low vacuum. Biomass was incubated in $125 \mathrm{ml}$ serum bottles with $80 \mathrm{ml}$ of $0.2 \mu \mathrm{m}$ filtered seawater. Acetylene $(9 \mathrm{ml})$ was added to the bottles and $2 \mathrm{ml}$ of gas from the headspace were immediately removed to Vacuettes (Greiner Bio-One, Kremsmünster, Austria) for $T_{0}$. Sample bottles (at neutral pressure), and appropriate blanks $(0.2 \mu \mathrm{m}$ filtered seawater and killed blanks) were incubated for $24 \mathrm{~h}$ in a flowing seawater bath at $25^{\circ} \mathrm{C}$ and $\sim 100 \mu \mathrm{mol}$ quanta $\mathrm{m}^{2} \mathrm{~s}^{-1}$. Ethylene production was measured with an FID-GC (SRI 310C) using known ethylene standards. Ethylene production was converted to $\mathrm{N}$-fixation rates according to Capone and Montoya (Capone and Montoya, 2001).

\section{Sample collection and processing for molecular analysis}

Twenty-liter samples were collected with Niskin bottles from each depth in the euphotic zone $(\sim 5$, 60, deep chlorophyll maximum and $150 \mathrm{~m}$ ). Each sample was placed into an acid-washed container and pumped using a peristaltic (Cole Parmer-Master Flex, Vernon Hills, IL, USA) pump onto $0.2 \mu \mathrm{m}$ pore-size Supor filters (Pall Gelman Inc., Ann Arbor, Michigan). The filter was then placed into a cryotube with $1 \mathrm{ml}$ of lysis buffer (Massana et al., 1997) and stored at $-80^{\circ} \mathrm{C}$ until further processing.

\section{Nucleic-acid extraction and reverse transcription}

Nucleic acids were extracted from the samples using a phenol-chloroform extraction according to Massana et al. (1997). Nucleic acids were treated with RNase-free DNase I (Ambion, Cambridgeshire, UK) for $30 \mathrm{~min}$ at $37^{\circ} \mathrm{C}$ to remove DNA residue. DNase was inactivated by heat denaturation at $75^{\circ} \mathrm{C}$ for $10 \mathrm{~min}$ and samples were stored at $-80^{\circ} \mathrm{C}$ until further use. Total RNA (100-300 ng) was then reverse transcribed using nifH degenerate reverse primer nifH3 $\left(5^{\prime}\right.$-ATRTTRTT NGCNGCRTA-3') and nifH723R (5'-GATGTTCGCGCGG CACGAADTRNATSA-3') using Bio-RT (Bio-Lab Ltd, Jerusalem, Israel) according to manufacturer's instructions.

\section{PCR amplification of nifH transcripts}

Nitrogenase Fe protein transcripts (nifH) were amplified from cDNA using the PCR primers of Zehr and McReynolds, (1989). A fragment of the nifH gene (approximately $360 \mathrm{bp}$ ) was amplified with a nested PCR strategy. The PCR mixtures contained $2.5 \mu \mathrm{l}$ of $10 \times$ ExTaq buffer (Takara, Madison, WI, USA), $2 \mu$ l of a mix of deoxynucleoside triphosphates ( $2.5 \mathrm{mM}$ each), $18.75 \mu \mathrm{l}$ of DEPC water, $0.25 \mu \mathrm{l}$ of $100 \mu \mathrm{M}$ nifH3 $\left(5^{\prime}\right.$-ATRTTRT TNGCNGCRTA-3'), $0.25 \mu \mathrm{l}$ of $100 \mu \mathrm{M}$ nifH4 (5'-TTYT AYGGNAARGGNGG-3') and $0.25 \mu \mathrm{l}$ of ExTaq DNA

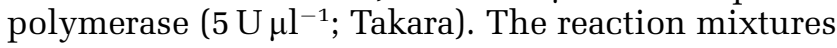

were amplified for one denaturation step ( $5 \mathrm{~min}$ at $94{ }^{\circ} \mathrm{C}$ ), followed by 30 cycles of $94^{\circ} \mathrm{C}$ for $1 \mathrm{~min}, 50^{\circ} \mathrm{C}$ for $1 \mathrm{~min}$ and $72^{\circ} \mathrm{C}$ for $1 \mathrm{~min}$, and one final 7 -min extension cycle at $72{ }^{\circ} \mathrm{C}$. To the nested PCR master mix, $0.5 \mu \mathrm{l}$ of the first PCR product and $0.5 \mu \mathrm{l}$ of DEPC water were then added. nifH primers previously designed (Zehr and McReynolds, 1989): $0.25 \mu \mathrm{l}$ of $100 \mu \mathrm{M}$ nifH1 (TGYGAYCCNAARGCNGA) and $0.25 \mu \mathrm{l}$ of $100 \mu \mathrm{M}$ nifH2 (ADNGCCATCA TYTCNCC). Second-round reactions were amplified with one denaturation step of $5 \mathrm{~min}$ at $94^{\circ} \mathrm{C}, 30$ cycles of $94^{\circ} \mathrm{C}$ for $1 \mathrm{~min}, 57^{\circ} \mathrm{C}$ for $1 \mathrm{~min}$ and $72^{\circ} \mathrm{C}$ for $1 \mathrm{~min}$, and a final 7 -min extension cycle at $72^{\circ} \mathrm{C}$. All of the tests for the presence of contaminating DNA in the RNA samples or in the reagent were carried out according to (Zani et al., 2000). PCR products were cloned using the QIAGEN-PCR cloning kit and selected clones were sequenced. The nifH sequences reported in this study are deposited with GenBank under accession numbers EU807710-EU807732.

\section{Phylogenetic analyses of nifH sequences}

nifH sequences were assembled and translated into amino-acid sequences using the SEQUENCHER program (version 4.5). All diversity and phylogenetic analyses were performed using deduced amino-acid sequences. $\mathrm{NifH}$ protein sequences were aligned using CLUSTALX version 1.81 (Thompson et al., 1997). Neighbor-joining and maximum-parsimony analyses were conducted on amino-acid data sets using Paup 4.0b10 (Swofford, 2002). Default parameters were used in all analyses. Bootstrap re-sampling of neighbor-joining (1000 replicates) and maximum-parsimony (1000 replicates) were performed.

\section{Results and discussion}

Study area

To examine spatial and temporal changes in $R$. intracellularis, one coastal (TB200) and one pelagic (TB1000) station, off the continental shelf, were sampled monthly during 2006-2007 (Figure 1). There were significant differences in the physical and chemical properties of the coastal and pelagic stations (Figure 2). The most apparent difference was the depth of the upper mixed layer during winter (January-March). At the coastal station, the winter deep mixing, which almost reached the bottom, could provide nutrients from the sediments while at the pelagic station, the deep mixing could not supply similar amount of nutrients from deeper layers.

The pelagic upper layer $(100 \mathrm{~m})$ had $\mathrm{NO}_{3}+\mathrm{NO}_{2}$, $\mathrm{PO}_{4}$ and $\mathrm{Si}(\mathrm{OH})_{4}$ concentrations of $<0.08-0.85 \mu \mathrm{M}$, $<0.008-0.11 \mu \mathrm{M}$ and $0.51-1.41 \mu \mathrm{M}$, respectively. Slightly higher concentrations of $\mathrm{PO}_{4}$ (up to $0.13 \mu \mathrm{M}$ ) and $\mathrm{Si}(\mathrm{OH})_{4}$ (up to $2.14 \mu \mathrm{M}$ ) were measured at the coastal station. These ranges of concentrations are consistent with previous studies from the Levantine basin (Berman et al., 1984; Azov, 1986; 
914

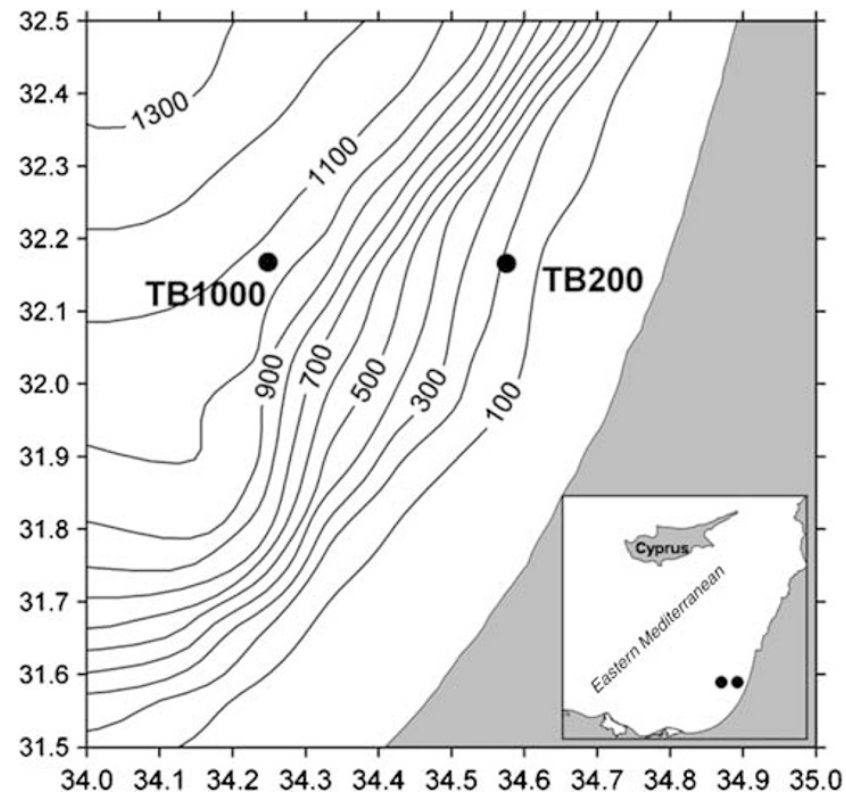

Figure 1 Map of the station locations: Station TB200, coastal station (on the continental shelf), bottom depth of $200 \mathrm{~m}$ $\left(32^{\circ} 09.982^{\prime} \mathrm{N}\right.$ and $\left.34^{\circ} 34.509^{\prime} \mathrm{E}\right)$ and a pelagic station, TB1000 with a bottom depth of $900 \mathrm{~m}$, off the continental shelf $\left(34^{\circ} 14.909^{\prime}\right.$ E and $32^{\circ} 10.059^{\prime} \mathrm{N}$ )

Bonin et al., 1989; Herut et al., 1999; Kress et al., 2005).

During stratified months (June-September) Chl $a$ concentrations peaked to $0.45 \mu \mathrm{gl}^{-1}$ at the DCM ( 110-150 m) while during winter mixing, the DCM $\left(\sim 0.4 \mu \mathrm{g} \mathrm{Chl} a \mathrm{l}^{-1}\right) \quad$ was widely spread between $50-130 \mathrm{~m}$ at the pelagic station and was not developed at the coastal station showing uniform vertical Chl $a$ distribution $\left(\sim 0.2-0.3 \mu \mathrm{gl}^{-1}\right)$. The highest photosynthetic biomass at both stations, estimated by Chl a concentrations and by variable fluorescence, occurred during the winter mixing.

Identification and characterization of the diatomdiazotroph associations

Using epifluorescent microscopy we identified the presence of the two main known diatom hosts of $R$. intracellularis from our two sampling stations: Rhizosolenia clevei var. communis and Hemiaulus hauckii. The cyanobiont $R$. intracellularis was present in all samples containing $H$. hauckii whereas it was only sporadically found in Rhizosolenia.

H. hauckii found in our study period was characterized by chains composed of 3-15 cells. Each cell contained one or two $R$. intracellularis trichomes though occasionally $H$. hauckii cells contained up to four $R$. intracellularis trichomes (see Figures 3a-d). The $R$. intracellularis trichome consisted of $3-5$ vegetative cells and one or two heterocysts at the end of each trichome depending on the size and stage of the H. hauckii$R$. intracellularis life cycle. The diameter of the
$H$. hauckii varied and averaged $\sim 30 \mu \mathrm{m}$ whereas the diatom chain could be as long as $200 \mu \mathrm{m}$. The average diameter of $R$. intracellularis inside H. hauckii was $\sim 10 \mu \mathrm{m}$.

Under bright-field light microscopy only the $H$. hauckii cells were apparent (Figure 3b). The distinguishing spindles connecting the $H$. hauckii cells and their length $(40 \mu \mathrm{m})$, enabled identification of the Hemiaulus as H. hauckii (Heinbokel, 1986; Kimor et al., 1987, 1992; Villareal, 1994). Under chlorophyll excitation only $H$. hauckii chloroplasts were visible (Figure 3a). The high chlorophyll autofluorescence of the diatom masked the chlorophyll contained in the cyanobiont vegetative cells. $R$. intracellularis was located in the diatom intercellular space (Villareal, 1991; Rai et al., 2000). The physical proximity between the cyanobiont and the diatom's chloroplasts may be due to the cyanobionts' high demand for carbohydrates (Wolk et al., 1994) required for the energetic costs of nitrogen fixation (Villareal, 1992; Janson et al., 1995a; Rai et al., 2000). Yet, we are not aware of any documented evidence for this carbon exchange.

The cyanobiont cells were visible only under phycocyanin or phycoerythrin (PE) excitation filters (Figures 3c,d,e,h, and i). These pigments are unique to the cyanobacterial endosymbionts (Villareal, 1992; Janson et al., 1995a; Rai et al., 2000) and are not found in the diatoms. Heterocysts appeared to contain high concentrations of PE (discernable by very high fluorescence under PE filters). This may be due to the pigment role in energy transfer to PSI or to the lack of protein degradation during heterocyst differentiation (Peterson, 1981; Fay, 1992; Janson et al., 1995a). Phycobiliproteins are also known to have a role in cyanobacterial nitrogen storage (Allen et al., 1984; Kromkamp, 1987). This increase in fluorescence might indicate that the heterocysts are using PE for an intracellular nitrogen storage facility (Figures 3d and i) (Wyman et al., 1985; Janson et al., 1995b; Wingard et al., 2002; Zhang et al., 2006). Nitrogen storage as $\mathrm{PE}$, combined with the close physical proximity between cyanobiont and host, may imply that nitrogen is rapidly assimilated once fixed by the $R$. intracellularis.

In Rhizosolenia spp. the trichomes of $R$. intracellularis lie within the diatom's periplasmatic space (Villareal, 1992; Janson et al., 1995b) and not between the host chloroplasts. Thus, under brightfield light microscopy, the vegetative cells of $R$. intracellularis were visible inside the Rhizosolenia and contained one to two trichomes with the heterocyst located toward the end of the Rhizosolenia valve (Figure 3e). The diameter of the Rhizosolenia cells varied between $20-30 \mu \mathrm{m}$ whereas the $\mathrm{R}$. intracellularis diameter was $\sim 10 \mu \mathrm{m}$. R. intracellularis contained $\sim 10$ vegetative cells with one enlarged heterocyst (Figures $3 \mathrm{~h}$ and i). The heterocysts were visible only when the organisms were excited with the PE or PC filter 
Stratified month

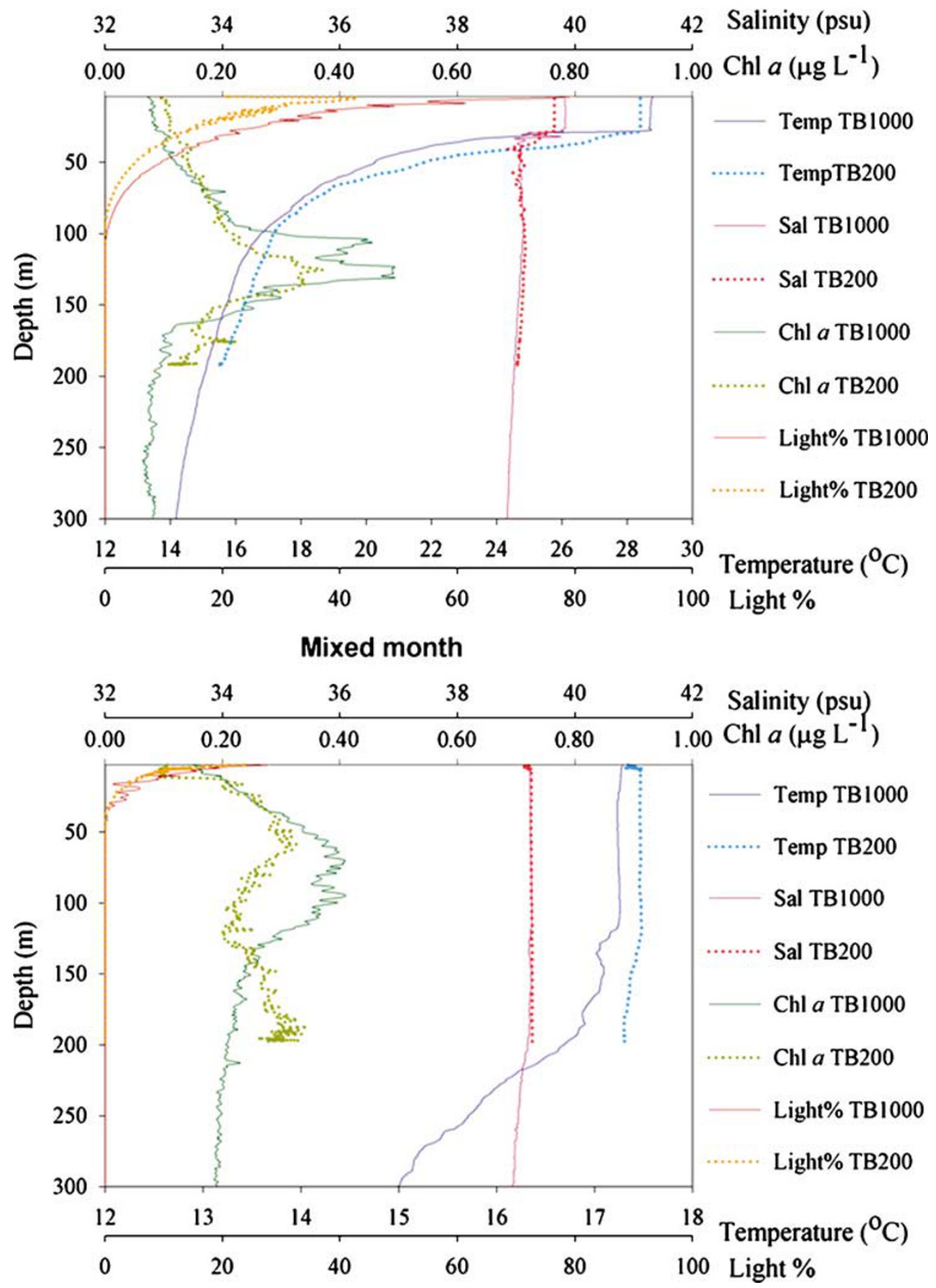

Figure 2 Representative depth profiles of the two sampling stations (TB200 and TB1000) during a stratified month (upper panel) and a mixed month (lower panel). In both panels parameter shown are: Temperature (blue and light blue), salinity, PSU (pink and red); Chl $a, \mu \mathrm{gl}^{-1}$ (green and light green); and \% light at depth (purple and orange).

sets. This might be due to low concentrations of Chl $a$ in these specialized nitrogen-fixing cells where no PSII activity occurs (Zhang et al., 2006). The diatom host can acquire their cyanobiont via two major pathways: either directly from the aquatic environment, or, through the parental cells following cell division (Villareal, 1989; Rai et al., 2000). The initiation mechanism is not known at present and the published literature on transmission and division is scarce (Villareal, 1989). Moreover, during our study period we did not observe any free living $R$. intracellularis as have been observed in other studies (Gomez et al., 2005; Foster and O’Mullen, in press). We observed the propagation of the symbiosis only via cellular division (Figure 4) and not by direct acquisition of symbionts from the seawater. Bright-field and epifluorescent microscopy revealed the division of the parent $H$. hauckii into two 

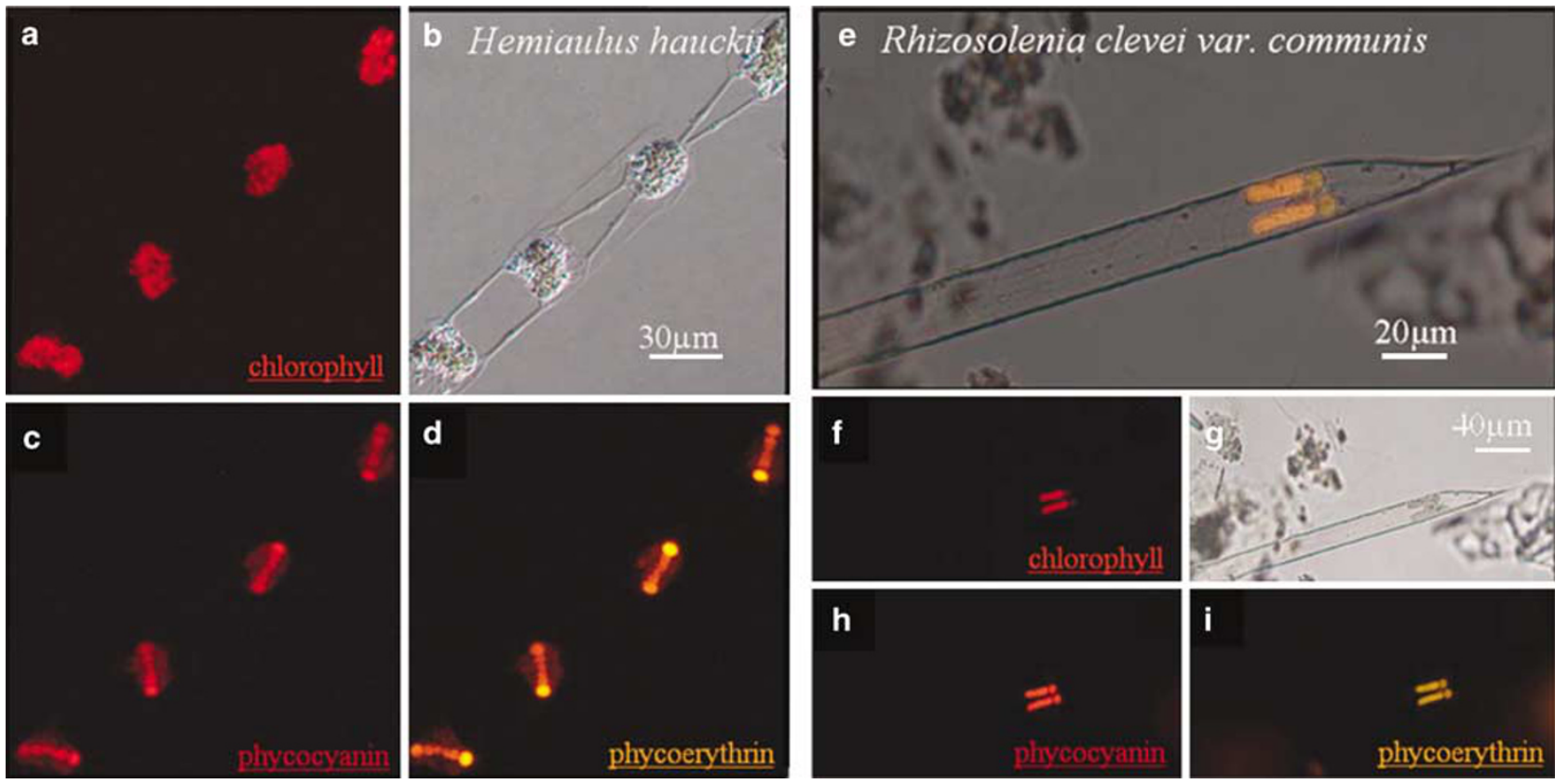

Figure 3 Diatom- Richelia symbioses. The diatom Hemiaulus hauckii and its endosymbiotic cyanobacterium Richelia intracellularis (a-d). The diatom Rhizosolenia spp and its endosymbiotic cyanobacterium Richelia intracellularis (e-i). (b, g) bright-field microscopy; $(a, f)$ chlorophyll $a$ fluorescence (ex: $450 \mathrm{~nm}$, em: $680 \mathrm{~nm}$ ); (d, i) phycoerythrin fluorescence (ex: $490 \mathrm{~nm}$, em: $580 \mathrm{~nm}$ ); (c.h) phycocyanin fluorescence (ex: 620, em: $660 \mathrm{~nm}$ ).

daughter cells (Figures 4a and b). Intertwined and visible under PE fluorescence, we also observed concurrent division of the symbiont $R$. intracellularis (Figure 4c). These results contrast with the asynchronous division reported from the only known culture of Rhizosolenia-Richelia that had been isolated, maintained, and was documented up to seven generations (Villareal, 1989). What controls the timing of those processes is still unknown. We hypothesize that nutrient cycling may play a significant role in cellular division of the DDA's, yet further work is required to validate this.

\section{Molecular identification and nifH expression}

of R. intracellularis

We confirmed the microscopical identification of the diatom-diazotroph associations using molecular tools. In both stations (TB200 and TB1000) water samples were collected during 2006 throughout the euphotic zone for molecular characterization of the symbiotic associations. Our recent study at an eastwest transect in the Levantine basin identified expressed nifH with high identity to $R$. intracellularis from size-fractionated samples between 11 to $60 \mu \mathrm{m}$ (Man-Aharonovich et al., 2007). Here, we expanded and sequenced a total of 52 randomly picked clones containing nifH inserts from samples $>0.2 \mu \mathrm{m}$ collected during daylight hours (as heterocystous cyanobacteria including Richelia are known to actively fix during the day). From the total clones that were sequenced, $54.5 \%$ had between 98-99\% identities at the DNA level to $R$. intracellularis, while only a small number of clones from each of the other diazotrophs were found representing any of the other diazotroph groups. This suggests that $R$. intracellularis is the main daytime nif $H$-expressing organism throughout the water column during our study period. We could not decipher from our phylogenetic analyses which organism (Rhizosolenia spp or $H$. hauckii) was the host of $R$. intracellularis (Figures 3a-d). However, as $>95 \%$ of the microscopical counts of the diatom containing the endosymbiont were of $H$. hauckii, we assume that $R$. intracellularis found in this study was predominantly from $H$. hauckii.

Surprisingly, all of the sequences that had high identity to $R$. intracellularis $(\sim 99 \%)$ fell into two nifH clusters, referred as Clusters A, B (Figure 5). Both subclades were statistically supported (bootstrap values $>80$ ) in the phylogenetic analysis based on amino-acid sequences. To examine the reasons for variation in the different clades from the two stations, we explored changes in the physical/ chemical characteristics of the water column (see area of study and Figures 2 and 6). Cluster A was comprised of $R$. intracellularis nifH sequences recovered from the pelagic station (TB1000) during the mixed period (February, March 2006) and throughout the euphotic zone from surface samples to $120 \mathrm{~m}$ depth. Cluster $\mathrm{B}$ was comprised of $R$. intracellularis nifH sequences recovered from the coastal station (TB200) during the mixedperiod (February, March 2006) and at the onset of stratification (May 2006). The only sequences 

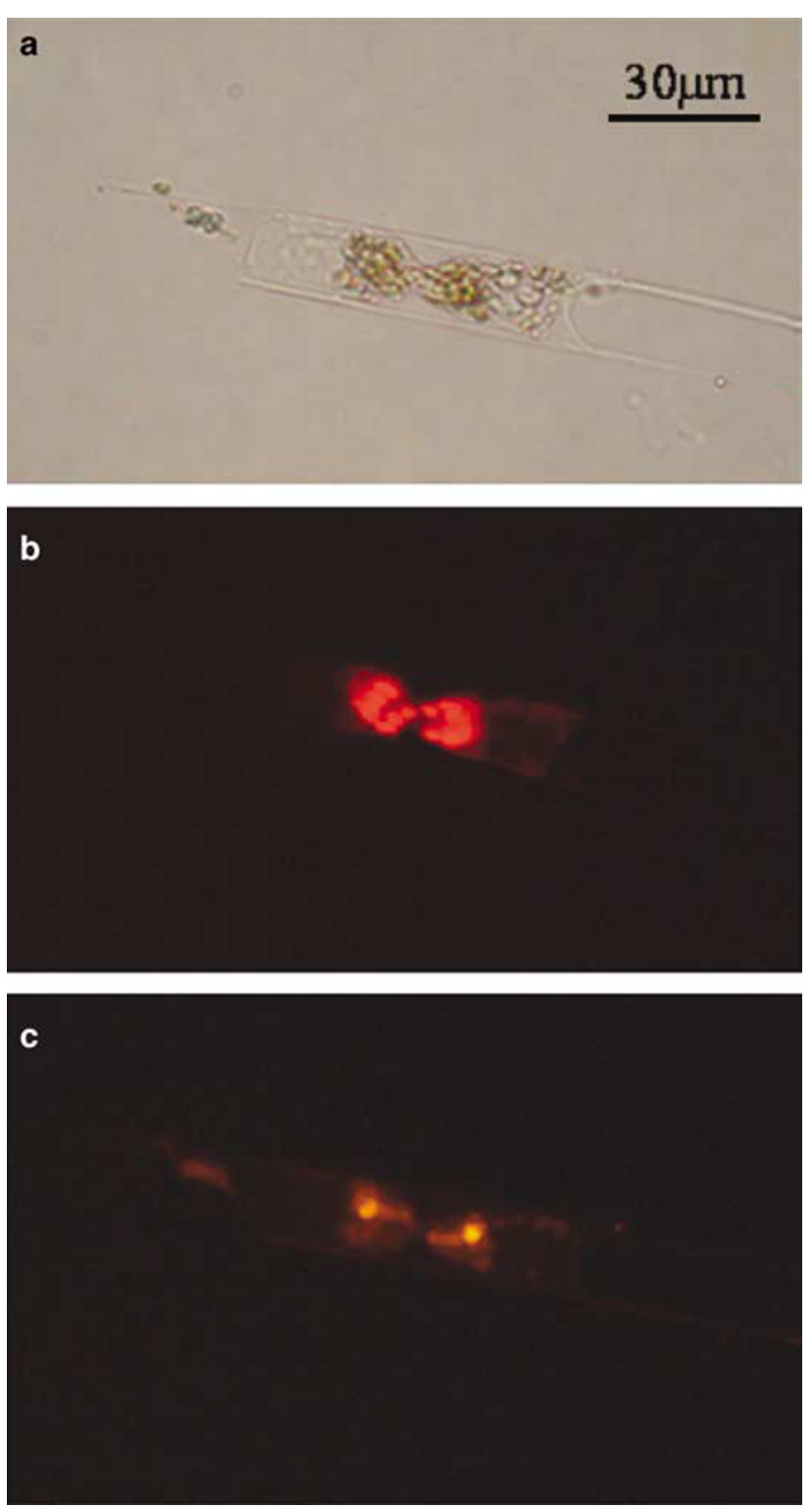

Figure 4 Cellular division of the diatom host and cyanobiont. Division of the diatom Hemiaulus hauckii under bright-field microscopy (a) with the diatom's chloroplast under Chlorophyll $a$ fluorescence (b), and the cyanobiont Richelia intracellularis under phycoerythrin fluorescence (c).

resulting from these months were from surface-layer samples.

We hypothesize that the regional circulation pattern (Rosentraub and Brenner, 2007) may play a significant role in the creation of the two different clades. The sharp continental slope located between the continental and pelagic station could generate a hydrological barrier (Rosentraub personal communication) that separates the phytoplankton community and thus also the $R$. intracellularis endosymbionts. Thus, while heterocyst abundance was similar at the two stations, the phylogenetic analysis revealed two distinct clades of $R$. intracellularis (Figure 5). Bacterial diversity may not always exhibit a specific taxa-area relationship due to small size, horizontal gene transfer, physiological flexibility and resilience to the environments (Horner-Devine et al., 2004a,b). Yet, taxa-area relationships have been found for bacterial populations driven by environmental heterogeneity (Horner-Devine et al., 2004b). The two distinct clades we found for Richelia from the two stations concurs with the above findings by (Horner-Devine et al., 2004b) or may present a case of allopatric speciation similar to isolated island populations that have emerged from one source population (Turelli et al., 2001). The presence of Richelia within the diatom-hosts in a complex association must also be accounted when examining distribution and diversity. Further investigation into the genetic profiles of the host diatoms would be necessary.

\section{Abundance and Nitrogen fixation}

$H$. hauckii and $R$. intracellularis were present throughout the year at both stations (TB200 and TB1000) (Figure 6) and were also counted during several night-time samplings. The rare sightings of Rhizosolenia-R. intracellularis associations in our stations correspond to results from a study in the Caribbean and North Atlantic Ocean where 91-100\% of Hemiaulus hosts contained the $R$. intracellularis symbionts while the RhizosoleniaRichelia associations were rarer (5-254 times less abundant than Hemiaulus-Richelia associations) (Villareal, 1994). Recently, Foster et al. (2007) reported that $H$. hauckii and $R$. intracellularis phylotypes were more abundant compared with the other diatom-diazotrophic symbioses in most stations and depths sampled during a cruise to the Western tropical North Atlantic Ocean. Accordingly, they suggested that under similar conditions, the smaller and more rapidly growing $H$. hauckii and $R$. intracellularis have a competitive advantage over the other diatom-diazotroph assemblages (Foster et al., 2007).

To date, we did not observe any substantial differences in heterocyst counts between the coastal station and the pelagic station except during October 2006 (11 heterocysts $\mathrm{l}^{-1}$ at the pelagic station and 52 heterocysts $\mathrm{l}^{-1}$ at the coastal station). In both stations heterocyst counts varied between 1-55 heterocysts $\mathrm{l}^{-1}$ and no significant bloom of $H$. hauckii-R. intracellularis was observed throughout the study period (Figure 6). Large blooms of the diatom-cyanobacterial association have been described in the tropical Atlantic, where heterocyst counts inside the bloom area ranged from hundreds to $>1000$ heterocysts $l^{-1}$ compared with 39 heterocysts $\mathrm{l}^{-1}$ outside the blooms (Villareal, 1994; Carpenter et al., 1999; Jahnke et al., 1999). Recent determinations of the $H$. hauckii-R. intracellularis associations by quantitative (Q)PCR of nifH gene copies showed similar abundances (Foster et al., 


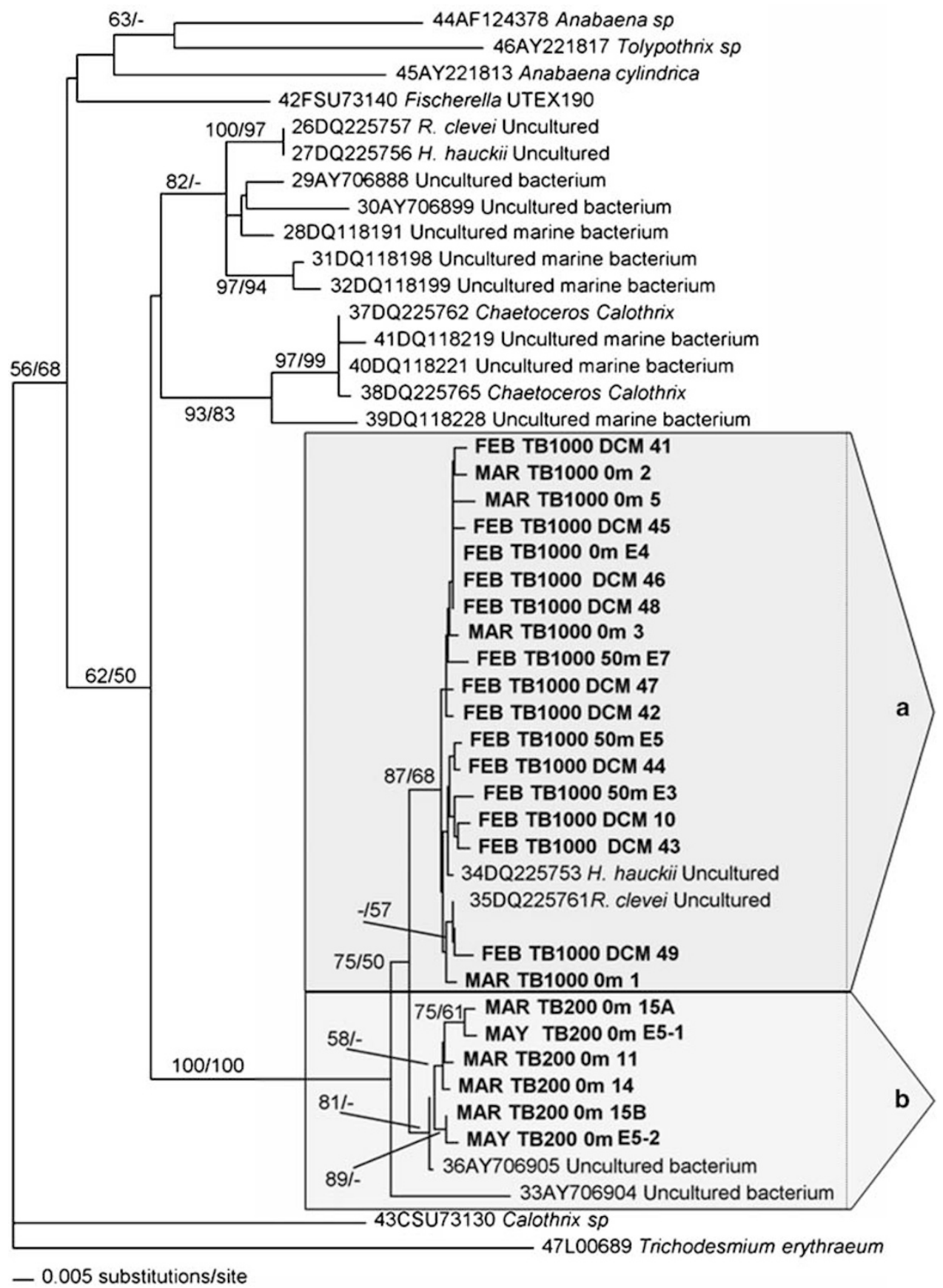

Figure 5 A Phylogenetic tree reconstructed from nifH-deduced amino-acid sequences. The sequences were obtained from the two sampling stations TB200 and TB1000 during 2006. The two groups obtained from the clone libraries sequences are marked in boldface letters. Bootstrap values (NJ/MP) exceeding $80 \%$ are indicated above the branches. The clusters (a) (open Ocean station-TB1000) and (b) (coastal station-TB200) represent the two groups.

2007). The highest numbers of heterocysts found at our coastal station (TB200) were counted in June and October $2006\left(\sim 50\right.$ heterocysts $\left.\mathrm{l}^{-1}\right)$ and at the pelagic station (TB1000) in June and November 2006 $\left(\sim 50\right.$ heterocysts $\left.l^{-1}\right)$. Figure 6 clearly shows a seasonal peak of heterocyst concentrations during autumn (October-November), coinciding with the deepening of the mixed-layer depth at both stations. Dust events, delivering nutrients, in particular P, are also characteristic during these months (autumn and spring) (Herut et al., 2002, 2005) and may enhance diatom-diazotroph occurrence.

Although total Richelia heterocyst counts were low, the actual presence of heterocysts and the expression of nifH detected by reverse transcribedPCR (Figure 5), indicates active nitrogen fixation. According to our microscopical and molecular identification, $R$. intracellularis was the dominant 
diazotroph in the $10-300 \mu \mathrm{m}$ fractions. For this size fraction $\mathrm{N}$-fixation rates averaged $\sim 1 \mathrm{nmol} \mathrm{N}^{-1}$ day $^{-1}$ at both stations, and throughout the photic zone during the sampling period, and comprised $50 \%-70 \%$ of the total $\mathrm{N}$-fixation rates measured $\left(0.4-4.5 \mathrm{nmol} \mathrm{N}^{-1}\right.$ day $^{-1}$ for $>1 \mu \mathrm{m}$ sizefraction). This is consistent with our findings that $54.5 \%$ of all sequenced clones were identified as $R$. intracellularis (see previous section Molecular identification and nifH expression).

A positive correlation was found between heterocyst numbers and the generally low nitrogen fixation rates only during stratified months (Figure 6, insert). We note that, at all times during the study period, to obtain any measurable rates of $\mathrm{N}$ fixation or statistically significant numbers of diazotrophs at our stations, we had to pre-concentrate large volumes of water. Species-specific rates of N-fixa-

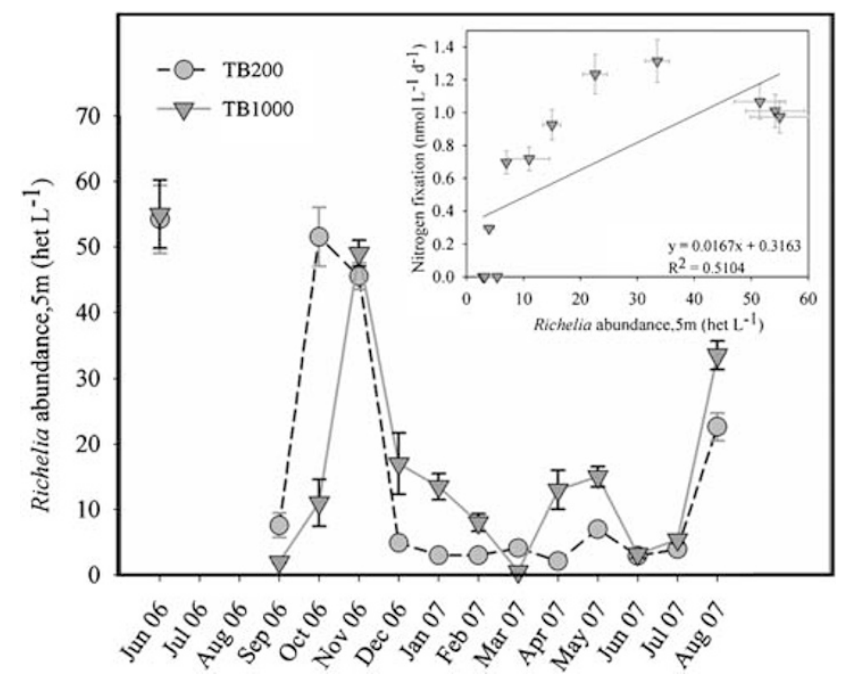

Figure 6 Spatial and temporal R.intracellularis heterocyst counts from surface waters $(\sim 5 \mathrm{~m})$ at our two representative stations TB1000-open Ocean (triangles) and TB200-coastal (circles) from May 2006 through August 2007. Insert shows correlation between above heterocyst counts and $\mathrm{N}$-fixation rates during stratified months only (May-September). tion by $R$. intracellularis as well as the total contribution of new $\mathrm{N}$ by DDA's and other diazotrophs to the N-budget of the Levantine basin remain uncharacterized and should be carefully examined at a wider scale. Moreover, our sampling and analyses for nifH expression performed predominantly during daytime does not take into account possible contributions of unknown active diazotrophs during night time. Yet, the low rates of $\mathrm{N}$-fixation measured during this study, combined with the low Richelia abundances and lack of DDA blooms (Figure 6), may reflect a scenario controlled by limited availability of essential nutrients as has been recorded for bacterial and primary productivity in the eastern Mediterranean (Herut et al., 2002; Flaten et al., 2005; Zohary et al., 2005; Tanaka et al., 2007).

In present day oceans, diatoms are almost the sole photoautotrophs with an absolute requirement for silicon in the form of silicic acid that is synthesized to form their frustules. Previous studies show that there is no significant difference in the seasonal silicic acid depth integrated values between the 120 (shelf) and $400 \mathrm{~m}$ (continental slope) stations (Herut et al., 2000). Moreover, the surface silicic acid concentrations in a westward section off the Mediterranean Israeli coast show no consistent gradient of lower concentrations towards the open sea, though seasonal changes are depicted in the range of $0.5-1.7 \mu \mathrm{mol} \mathrm{l}^{-1}$ (Kress and Herut, unpublished data).

We examined whether the seasonal and depthrelated changes in $\mathrm{Si}(\mathrm{OH})_{4}$ and $\mathrm{NO}_{3}+\mathrm{NO}_{2}$ influenced diatom-diazotroph abundance (Figure 7). The ratio between $\mathrm{Si}(\mathrm{OH})_{4} / \mathrm{NO}_{3}+\mathrm{NO}_{2}$ was used to indicate the relative availability of these nutrients. For non-symbiotic diatoms, blooms can occur when $\mathrm{Si}, \mathrm{P}$ and bioavailable nitrogen sources (other than atmospheric nitrogen) are high (leading to a low $\mathrm{Si}(\mathrm{OH})_{4} / \mathrm{NO}_{3}+\mathrm{NO}_{2}$ ratio). A high ratio of $\mathrm{Si}$ to bioavailable $\mathrm{N}$ could provide a competitive advantage to the diatom-diazotroph associations where $\mathrm{N}$ is supplied via biological $\mathrm{N}$-fixation.
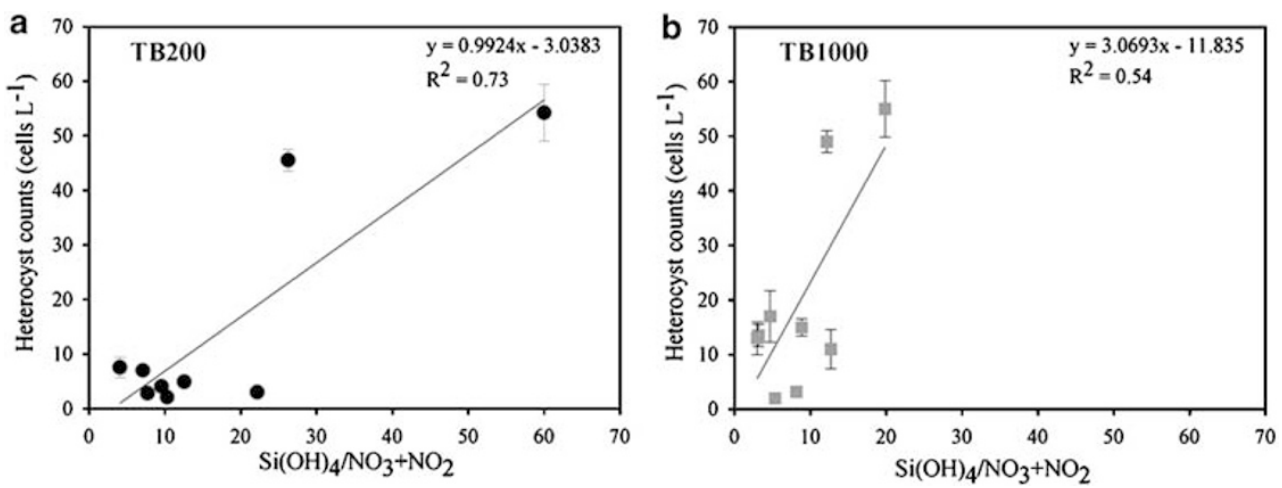

Figure 7 Correlations between $\mathrm{Si}(\mathrm{OH})_{4} /\left(\mathrm{NO}_{3}+\mathrm{NO}_{2}\right)$ and counts of Richelia heterocysts (het $\left.\mathrm{l}^{-1}\right)$ from the coastal station TB200 (a) and the pelagic station TB1000 (b). Heterocysts were always counted within the diatom hosts. 
We observed a positive correlation between the heterocyst counts (all heterocysts counted were within diatom hosts) and the $\mathrm{Si}(\mathrm{OH})_{4} / \mathrm{NO}_{3}+\mathrm{NO}_{2}$ (Figure 7). Although during the observations of the $H$. hauckii-R. intracellularis association the diatom/ heterocyst ratio was not necessarily 1:1, we found a positive relationship between heterocyst and diatom counts. As $\mathrm{Si}(\mathrm{OH})_{4}$ concentrations did not increase or decline significantly at the two sampling stations to concentrations that would limit diatom growth, we deduce that the reduction in bioavailable $\mathrm{N}$ sources, such as nitrite and nitrate, stimulated increased N-fixation and enhanced the growth of symbiotic diatom-diazotroph associations.

For large-scale blooms of diatom-diazotroph symbioses such as $H$. hauckii, Rhizosolenia and $R$. intracellularis to form and persist requires two other essential nutrients: Fe and P. In the Eastern Mediterranean Fe availability may actually be quite high (Guerzoni et al., 1999). In contrast, $\mathrm{P}$ concentrations are at the nanomolar scale in the upper layers (Krom et al., 2005) causing intense competition between autotrophic and heterotrophic plankton for this limited resource (Psarra et al., 2005; Thingstad et al., 2005; Zohary et al., 2005).

Diatoms, with relatively small surface area/volume (SA/V), are competitively disadvantaged compared with the picoplankton's large SA/V ratio and high nutrient uptake rates that are suited for this ultraoligotrophic system. Thus, in the Eastern Mediterranean open Ocean where $\mathrm{P}$ is extremely limited (Flaten et al., 2005), we would not expect to find large-scale blooms of diatoms (Psarra et al., 2005) or the associations of H. hauckii, Rhizosolenia and $R$. intracellularis. This is consistent with our findings of limited abundances of both the diatom hosts and the diazotrophic cyanobacterial symbiont requiring high $\mathrm{P}$.

Data from the late Pleistocene Mediterranean sapropels, including samples from the Levantine basin, show an annually-repeating seasonal flux dominated by Rhizosolenid diatoms including H. hauckii (Kemp et al., 1999) Richelia endosymbionts were not actually preserved in the sapropels. Yet the isotopic signatures of ${ }^{15} \mathrm{~N} /{ }^{14} \mathrm{~N}$ from these sapropels, suspended particles and extracted chlorophyll, have prompted claims that large diazotrophic blooms occurred and contributed $70-90 \%$ of new $\mathrm{N}$ to the Eastern Mediterranean (Sachs and Repeta, 1999; Pantoja et al., 2002). Those blooms could have formed in the past due to a shallower pycnocline (resulting from larger freshwater fluxes into the basin with high $\mathrm{Si}$ and $\mathrm{P}$ ) and thus nutrientenrichment of the euphotic layer (Sachs and Repeta, 1999; Pantoja et al., 2002). Moreover, such enhancement of carbon export may have triggered or amplified denitrification rates generating nitrogen deficient-water that would fuel subsequent nitrogen fixation (Deutsch et al., 2007).

Will large blooms of DDA's occur again in the Mediterranean? Future scenarios predict the enhancement of the scale and frequency of anthropogenic and/or atmospheric (for example, via Saharan dust) input of nutrients having combined $\mathrm{N}: \mathrm{P} \gg 16$ and high Fe. These conditions could result in one of two scenarios. If $\mathrm{P}$ is still limiting, and limited denitrification continues, nitrogen-fixation in this area would remain low. Alternatively, the geophysical characteristics of the semi-enclosed basin of the eastern Mediterranean combined with higher inputs of nutrients could increase the inventories of limiting resources such as $P$ as well as those of dissolved $\mathrm{Fe}$ and shift the system towards mesotrophy. Moreover, the global shift in temperatures may cause reduced circulation and the formation of anoxic conditions as well as an increase in shelf areas due to enhanced coastal flooding. These conditions could promote increased denitrification rates and subsequent loss of dissolved nitrate source, thereby enhancing nitrogenfixation and primary productivity (Deutsch et al., 2007) and enabling diatom-diazotroph blooms.

\section{Acknowledgements}

We thank the Captain (Dani Sheffer) and Engineer (Etai Catzman) of the R/V Mediterranean Explorer and the EcoOcean Marine Research and Education Organization as well as the captain and crew of the R/V Shikmona for their expert assistance at sea. The R/V Shikmona cruises were funded by a donation of the Israel Oceanographic and Limnological Research North American Friends. Many thanks to $\mathrm{R}$ Foster for bringing to our attention the importance of the diatom-diazotroph symbioses as well as for insightful suggestions, tips, and much help throughout. Thanks to B Kimor, E Carpenter, and $\mathrm{N}$ Gordon for aid in identification of the diatom-diazotrophs and to E Rahav for technical help at sea. We thank I Gertman from IOLR for generating Figure 1. This research is part of the requirements for an MSc thesis for EB-Z and for a Ph D thesis for TY at Bar Ilan University. This study is supported by an Israel Science Foundation Grant (No. 458/04) to IB-F and OB.

\section{References}

Allen MM, Morris R, Zimmerman W. (1984). Cyanophycin granule polypeptide protease in a unicellular cyanobacterium. Arch Microbiol 138: 119-123.

Arrigo KR. (2005). Marine microorganisms and global nutrient cycles. Nature 438: 122.

Azov Y. (1986). Seasonal patterns of phytoplankton productivity and abundance in near shore oligotrophic waters of the Levant basin (Mediterranean). J Plankton Res 8: 41-53.

Berman T, Townsend DW, Elsayed SZ, Trees CC, Azov Y. (1984). Optical transparency, chlorophyll and primary productivity in the Eastern Mediterranean near the Israeli coast. Oceanologica Acta 7: 367-372.

Bethoux BJP. (1986). Biological fixation of atmospheric nitrogen in the Mediterranean Sea. Limnology and Oceanography 31: 1353-1358. 
Bethoux JP, de Madron XD, Nyffeler F, Tailliez D. (2002). Deep water in the Western Mediterranean: Peculiar 1999 and 2000 characteristics, shelf formation hypothesis, variability since 1970 and geochemical inferences. J Mar Syst 33: 117-131.

Bethoux JP, Morin P, Chaumery C, Connan O, Gentili B, Ruiz-Pino D. (1998). Nutrients in the Mediterranean Sea, mass balance and statistical analysis of concentrations with respect to environmental change. Mar Chem 63: 155-169.

Bethoux JP, Morin P, Madec C, Gentili B. (1992). Phosphorus and nitrogen behavior in the Mediterranean-Sea. Deep-Sea Research Part I-Oceanographic Research Papers 39: 1641-1654.

Bonin DJ, Bonin MC, Berman T. (1989). Experimentalevidence of nutrients limiting the production of micronanoplankton and ultraplankton in the coastal waters of the Eastern Mediterranean Ocean (Haifa, Israel). Aquat Sci 51: 129-152.

Capone DG. (1993). Determination of nitrogenase activity in aquatic samples using the acetylene reduction procedure. In: Kemp PF, Sherr B, Sherr E, Cole J (eds). Handbook of Methods in Aquatic Microbial Ecology. pp 621-631.

Capone DG, Montoya JP. (2001). Nitrogen fixation and denitrification. Methods Microbiol 30: 501-515.

Capone DG, Zehr JP, Paerl HW, Bergman B, Carpenter EJ. (1997). Trichodesmium, a globally significant marine cyanobacterium. Science 276: 1221-1229.

Carpenter EJ, Montoya JP, Burns J, Mulholland MR, Subramaniam A, Capone DG. (1999). Extensive bloom of a $\mathrm{N}_{2}$-fixing diatom/cyanobacterial association in the tropical Atlantic Ocean. Mar Ecol-Prog Ser 185: 273-283.

Carpenter EJ, Romans K. (1991). Major role of the cyanobacterium Trichodesmium in nutrient cycling in the North-Atlantic Ocean. Science 254: 1356-1358.

Deutsch C, Sarmiento JL, Sigman DM, Gruber N, Dunne JP. (2007). Spatial coupling of nitrogen inputs and losses in the ocean. Nature 445: 163-167.

Falcon LI, Carpenter EJ, Cipriano F, Bergman B, Capone DG. (2004). $\mathrm{N}_{2}$ fixation by unicellular bacterioplankton from the Western and Pacific Oceans: Phylogeny and in situ rates. Appl Environ Microbiol 70: 765-770.

Falcon LI, Cipriano F, Chistoserdov AY, Carpenter EJ. (2002). Diversity of diazotrophic unicellular cyanobacteria in the tropical North Atlantic Ocean. Appl Environ Microbiol 68: 5760-5764.

Fay P. (1992). Oxygen relations of nitrogen-fixation in cyanobacteria. Microbiol Rev 56: 340-373.

Flaten GAF, Skjoldal EF, Krom MD, Law CS, Mantoura RFC, Pitta P et al. (2005). Studies of the microbial Pcycle during a lagrangian phosphate-addition experiment in the Eastern Mediterranean. Deep-Sea Research Part II-Topical Studies in Oceanography 52: 2928-2943.

Foster RA, O’Mullen GD. (In press). Nitrogen-fixing and nitrifying symbioses in the marine environment. In: Capone, DG, Bronk D, Mulholland MR, Carpenter EJ (eds). Nitrogen in the Marine Environment. Academic Press/Elsevier: San Diego.

Foster RA, Subramaniam A, Mahaffey C, Carpenter EJ, Capone DG, Zehr JP. (2007). Influence of the Amazon river plume on distributions of free-living and symbiotic cyanobacteria in the Western tropical North Atlantic ocean. Limnol Oceanography 52: 517-532.
Garcia N, Raimbault P, Gouze E, Sandroni V. (2006). Nitrogen fixation and primary production in Western Mediterranean. Comptes Rendus Biologies 329: 742-750.

Geitler L. (1932). Cyanophyceae. In: Rabenhorst L. (ed). Rabenhorst's Kryptogamen-Flora von Deutchland, Österreich und der Schweiz, vol. 14. Akademische Verlagsgesellschaft, Leipzig. pp 1-1196.

Gomez F, Furuya K, Takeda S. (2005). Distribution of the cyanobacterium Richelia intracellularis as an epiphyte of the diatom Chaetoceros compressus in the Western Pacific Ocean. J Plankton Res 27: 323-330.

Guerzoni S, Chester R, Dulac F, Herut B, Loye-Pilot MD, Measures $C$ et al. (1999). The role of atmospheric deposition in the biogeochemistry of the Mediterranean Sea. Prog Oceanography 44: 147-190.

Heinbokel J. (1986). Occurrence of Richelia intracellularis (cyanophyta) within the diatoms Hemiaulus Haukii and H. Membranaceus off Hawaii. J Phycol 22: 399-403.

Herut B, Collier R, Krom MD. (2002). The role of dust in supplying nitrogen and phosphorus to the Southeast Mediterranean. Limnol Oceanography 47: 870-878.

Herut B, Zohary T, Krom MD, Mantoura RFC, Pitta P, Psarra $S$ et al. (2005). Response of East Mediterranean surface water to Saharan dust: on-board microcosm experiment and field observations. Deep-Sea Research Part II-Topical Studies in Oceanography 52: 3024-3040.

Herut B, Zohary T, Robarts RD, Kress N. (1999). Adsorption of dissolved phosphate onto loess particles in surface and deep Eastern Mediterranean water. Mar Chem 64: 253-265.

Horner-Devine MC, Carney KM, Bohannan BJM. (2004a). An ecological perspective on bacterial biodiversity. Proc $R$ Soc Lond Ser B 271: 113-122.

Horner-Devine MC, Lage M, Hughes JB, Bohannan BJM. (2004b). A taxa-area relationship for bacteria. Nature 432: $750-753$.

Ignatiades L, Psarra S, Zervakis V, Pagou K, Souvermezoglou E, Assimakopoulou G et al. (2002). Phytoplankton size-based dynamics in the Aegean Sea (Eastern Mediterranean). J Mar Syst 36: 11-28.

Jahnke LL, Summons RE, Hope JM, des Marais DJ. (1999). Carbon isotopic fractionation in lipids from methanotrophic bacteria II: The effects of physiology and environmental parameters on the biosynthesis and isotopic signatures of biomarkers. Geochimica Et Cosmochimica Acta 63: 79-93.

Janson S, Carpenter EJ, Bergman B. (1995a). Immunolabeling of phycoerythrin, ribulose 1,5-bisphosphate carboxylase oxygenase and nitrogenase in the unicellular cyanobionts of Ornithocercus spp (dinophyceae). Phycologia 34: 171-176.

Janson S, Rai AN, Bergman B. (1995b). Intracellular cyanobiont Richelia-intracellularis-ultrastructure and immuno-localization of phycoerythrin, nitrogenase, rubisco and glutamine-synthetase. Mar Biol 124: $1-8$.

Janson S, Wouters J, Bergman B, Carpenter EJ. (1999). Host specificity in the Richelia-diatom symbiosis revealed by hetR gene sequence analysis. Environ Microbiol 1: 431-438.

Kemp AES, Pearce RB, Koizumi I, Pike J, Rance SJ. (1999). The role of mat-forming diatoms in formation of Mediterranean sapropels. Nature 398: 57-61.

Kimor B, Berman T, Schneller A. (1987). Phytoplankton assemblages in the deep chlorophyll maximum layers 
off the Mediterranean coast of Israel. J Plankton Res $\mathbf{9}$ : 433-443.

Kimor B, Gordon N, Neori A. (1992). Symbiotic associations among the microplankton in oligotrophic marine environments, with special reference to the Gulf of Aqaba, Red Sea. J Plankton Res 14: 1217-1231.

Kress N, Thingstad TF, Pitta P, Psarra S, Tanaka T, Zohary $\mathrm{T}$ et al. (2005). Effect of $\mathrm{P}$ and $\mathrm{nN}$ addition to oligotrophic Eastern Mediterranean waters influenced by near-shore waters: a microcosm experiment. DeepSea Research Part II-Topical Studies in Oceanography 52: 3054-3073.

Krom MD, Woodward EMS, Herut B, Kress N, Carbo P, Mantoura RFC et al. (2005). Nutrient cycling in the south East Levantine basin of the Eastern Mediterranean: results from a phosphorus starved system. DeepSea Research Part II-Topical Studies in Oceanography 52: 2879-2896.

Kromkamp J. (1987). Formation and functional significance of storage products in cyanobacteria. New Zealand J Mar Freshwater Res 21: 457-465.

Li WKW, Zohary T, Yacobi YZ, Wood AM. (1993). Ultraphytoplankton in the Eastern MediterraneanSea-towards deriving phytoplankton biomass from flow cytometric measurements of abundance, fluorescence and light scatter. Mar Ecol-Prog Ser 102: 79-87.

Mague TH, Mague FC, Holmhansen O. (1977). Physiology and chemical composition of nitrogen-fixing phytoplankton in central North Pacific Ocean. Mar Biol 41: 213-227.

Man-Aharonovich D, Kress N, Bar Zeev E, Berman-Frank I, Beja O. (2007). Molecular ecology of nifH genes and transcripts in the Eastern Mediterranean Sea. Environ Microbiol 9: 2354-2363.

Massana R, Murray A, Preston C, DeLong E. (1997). Vertical distribution and phylogenetic characterization of marine planktonic archaea in the Santa Barbara channel. Appl Environ Microbiol 63: 50-56.

Montoya JP, Holl CM, Zehr JP, Hansen A, Villareal TA, Capone DG. (2004). High rates of $\mathrm{N}_{2}$ fixation by unicellular diazotrophs in the oligotrophic Pacific Ocean. Nature 430: 1027-1031.

Pantoja S, Repeta DJ, Sachs JP, Sigman DM. (2002). Stable isotope constraints on the nitrogen cycle of the Mediterranean Sea water column. Deep-Sea Research Part I-Oceanographic Research Papers 49: 1609-1621.

Peterson RB, Dolan E, Calvert HE, Ke B. (1981). Energy transfer from phycobiliproteins to photosystem I in vegetative cells and heterocysts of anabaena variabilis. Biochim Biophys Acta 12: 237-248.

Psarra S, Tselepides A, Ignatiades L. (2000). Primary productivity in the oligotrophic Cretan Sea (NE Mediterranean): seasonal and interannual variability. Prog Oceanography 46: 187-204.

Psarra S, Zohary T, Krom MD, Mantoura RFC, Polychronaki T, Stambler N et al. (2005). Phytoplankton response to a lagrangian phosphate addition in the Levantine Sea (Eastern Mediterranean). Deep-Sea Research Part II-Topical Studies in Oceanography 52: 2944-2960.

Rai AN, Soderback E, Bergman B. (2000). Cyanobacteriumplant symbioses. New Phytologist 147: 449-481.

Rees AP, Law CS, Woodward EMS. (2006). High rates of nitrogen fixation during an in-situ phosphate release experiment in the Eastern Mediterranean Sea. J Geophysical Res Lett 33: L10607, doi:10.1029/ $2006 G L 025791$.
Rosentraub Z, Brenner S. (2007). Circulation over the southeastern continental shelf and slope of the Mediterranean Sea: direct current measurements, winds, and numerical model simulations. J Geophys Res 112: C11001, doi:10.1029/2006JC003775.

Sachs JP, Repeta DJ. (1999). Oligotrophy and nitrogen fixation during Eastern Mediterranean sapropel events. Science 286: 2485-2488.

Sundstrom BG. (1984). Observations on Rhizosoleniaclevei ostenfeld (bacillariophyceae) and Richeliaintracellularis schmidt (cyanophyceae). Botanica Marina 27: 345-355.

Swofford DL. (2002). Paup*. Phylogenetic Analysis using Parsimony. Sinauer Associates: Sunderland, MA, USA.

Tanaka T, Zohary T, Krom MD, Law SC, Pitta P, Psarra S et al. (2007). Microbial community structure and function in the Levantine basin of the Eastern Mediterranean. Deep-Sea Research Part I-Oceanographic Research Papers 54: 1721-1743.

Taylor FJR. (1982). Symbioses in marine microplankton. Annales De L Institut Oceanographique 58: 61-90.

Thingstad TF, Krom MD, Mantoura RFC, Flaten GAF, Groom S, Herut B et al. (2005). Nature of phosphorus limitation in the ultraoligotrophic Eastern Mediterranean. Science 309: 1068-1071.

Thompson JD, Gibson TJ, Plewniak F, Jeanmougin F, Higgins DG. (1997). The CLUSTAL-X Windows interface: flexible strategies for multiple sequence alignment aided by quality analysis tools. Nucleic Acids Res 25: 4876-4882.

Turelli M, Barton NH, Coyne JA. (2001). Theory and speciation. Trends Ecol Evolution 16: 330-343.

Venrick EL. (1974). Distribution and significance of Richelia-intracellularis schmidt in North Pacific central gyre. Limnol Oceanography 19: 437-445.

Vidussi F, Claustre H, Manca BB, Luchetta A, Marty JC. (2001). Phytoplankton pigment distribution in relation to upper thermocline circulation in the Eastern Mediterranean Sea during winter. J Geophysical ResOceans 106: 19939-19956.

Villareal T. (1994). Widespread occurrence of the Hemiaulus-cyanobacterial symbiosis in the Southwest North Atlantic Ocean. Bull Mar Sci 54: 1-7.

Villareal TA. (1989). Division cycles in the nitrogen-fixing Rhizosolenia (bacillariophyceae) Richelia (nostocaceae) symbiosis. Br Phycol J 24: 357-365.

Villareal TA. (1991). Nitrogen-fixation by the cyanobacterial symbiont of the diatom genus Hemiaulus. Mar Ecol-Prog Ser 76: 201-204.

Villareal TA. (1992). Buoyancy properties of the giant diatom Eethmodiscus. J Plankton Res 14: 459-463.

Wingard LL, Miller SR, Sellker JM, Stenn E, Allen MM, Wood AM. (2002). Cyanophycin production in a phycoerythrin-containing marine Synechococcus strain of unusual phylogenetic affinity. Appl Environ Microbiol 68: 1772-1777.

Wolk CP, Ernst A, Elhai J. (1994). Heterocyst metabolism and development. In: Bryant DA (ed). The Molecular Biology of Cyanobacteria. Dordrecht, Kluwer Academic Publishers: the Netherlands. pp 769-823.

Wyman M, Gregory RPF, Carr NG. (1985). Novel role for phycoerythrin in a marine cyanobacterium, Synechococcus strain DC2. Science 230: 818-820.

Yacobi YZ, Zohary T, Kress N, Hecht A, Robarts RD, Waiser $\mathrm{M}$ et al. (1995). Chlorophyll distribution throughout the Southeastern Mediterranean in 
relation to the physical structure of the water mass. J Mar Syst 6: 179-190.

Zani S, Mellon MT, Collier JL, Zehr JP. (2000). Expression of nifH genes in natural microbial assemblages in Lake George, New York, detected by reverse transcriptase PCR. Appl Environ Microbiol 66: 3119-3124.

Zehr JP, Bench SR, Mondragon EA, McCarren J, DeLong EF. (2007). Low genomic diversity in tropical oceanic $\mathrm{N}_{2}$-fixing cyanobacteria. Proc Natl Acad Sci 104: 17807-17812.

Zehr JP, McReynolds LA. (1989). Use of degenerate oligonucleotides for amplification of the nifH gene from the marine cyanobacterium Trichodesmium thiebautii. Appl Environ Microbiol 55: 2522-2526.
Zehr JP, Waterbury JB, Turner PJ, Montoya JP, Omoregie E, Steward GF et al. (2001). Unicellular cyanobacteria fix $\mathrm{N}_{2}$ in the subtropical North Pacific Ocean. Nature 412: 635-638.

Zhang C-C, Laurent S, Sakr S, Peng L, Bédu S. (2006). Heterocyst differentiation and pattern formation in cyanobacteria: a chorus of signals. Mol Microbiol 59: 367-375.

Zohary T, Herut B, Krom MD, Mantoura RFC, Pitta P, Psarra $\mathrm{S}$ et al. (2005). P-limited bacteria but $\mathrm{N}$ and $\mathrm{P}$ co-limited phytoplankton in the Eastern Mediterranean-a microcosm experiment. Deep-Sea Research Part II-Topical Studies in Oceanography 52: 3011-3023. 